\title{
Correlation of intravesical prostatic protrusion with severity of lower urinary symptoms among patients with benign prostatic hyperplasia
}

\author{
Babatunde K. Hamza ${ }^{1,2^{*}}$ (D), Muhammed Ahmed ${ }^{2}$, Ahmad Bello $^{2,3}$, Musliu Adetola Tolani $^{2,3}$, Mudi Awaisu $^{2,3}$, \\ Ahmad Tijjani Lawal ${ }^{2,3}$, Nasir Oyelowo ${ }^{2,3}$, Khalifah Ibrahim Abdulsalam², Lateef Lawal ${ }^{2}$, Abdullahi Sudi $^{3}$ \\ and Hussein Yusuf Maitama ${ }^{2,3}$
}

\begin{abstract}
Background: Benign prostate hyperplasia (BPH) is characterized by an increase in the number of epithelial and stromal cells in the periurethral area of the prostate. Lower urinary tract symptoms (LUTS) often develop as a manifestation of bladder outlet obstruction (BOO) due to benign prostate enlargement. When the prostate enlarges, protrusion into the bladder often occurs as a result of morphological changes of the gland. Prostatic protrusion into the bladder can be measured with ultrasound as intravesical prostatic protrusion (IPP). There are studies that have shown IPP as a reliable predictor of bladder obstruction index $(\mathrm{BOOI})$ as measured by pressure flow studies. IPP is thereby reliable in assessing the severity of $\mathrm{BOO}$ in patients with $\mathrm{BPH}$. The severity of symptoms in patients with $\mathrm{BPH}$ can be assessed through several scoring systems. The most widely used symptoms scoring system is the International Prostate Symptoms Score (IPSS). The aim of this study is to determine the correlation of IPP with IPSS in men with BPH at our facility.

Methods: The study was a cross-sectional observational study that was conducted at the Division of Urology, Department of Surgery, in our facility. The study was conducted on patients greater than 50 years LUTS and an enlarged prostate on digital rectal examination and/or ultrasound. All consenting patients were assessed with the International Prostate Symptoms Score (IPSS) questionnaire, following which an abdominal ultrasound was done to measure the intravesical prostatic protrusion (IPP), prostate volume (PV) and post-void residual (PVR) urine. All the patients had uroflowmetry, and the peak flow rate was determined. The data obtained were entered into a proforma. The results were analyzed using Statistical Package for Social Sciences (SPSS) software package version 20.

Results: A total of 167 patients were seen during the study period. The mean age was $63.7 \pm 8.9$ years, with a range of $45-90$ years. The mean IPSS was $18.24 \pm 6.93$, with a range of $5-35$. There were severe symptoms in $49.1 \%$, while $43.1 \%$ had moderate symptoms and $7.8 \%$ had mild symptoms. The overall mean IPP was $10.3 \pm 8 \mathrm{~mm}$. Sixty-two patients (37.1\%) had grade I IPP, 21 patients (12.6\%) had grade II IPP and 84 patients (50.3\%) had grade III IPP. The mean prostate volume and peak flow rate were $64 \mathrm{~g} \pm 34.7$ and $11.6 \mathrm{ml} / \mathrm{s} \pm 5.4$, respectively. The median PVR was $45 \mathrm{ml}$ with a range of $0-400 \mathrm{ml}$. There was a significant positive correlation between the IPP and IPSS $(P=0.001)$. IPP also had a significant positive correlation with prostate volume and post-void residual and a significant negative correlation with the peak flow rate $(P<0.01)$.
\end{abstract}

\footnotetext{
*Correspondence: ridwankolapo@yahoo.com

${ }^{1}$ Kaduna State University, Kaduna, Nigeria

Full list of author information is available at the end of the article
} 
Conclusion: Intravesical prostatic protrusion is a reliable predictor of severity of LUTS as measured by IPSS, and it also shows good correlation with other surrogates of bladder outlet obstruction.

\section{Background}

Benign prostate hyperplasia is a condition intimately related to aging [1]. Histologically, it is a hyperplastic process that develops in the transition zone resulting from an increase in cell number. Microscopic evaluation reveals a nodular growth pattern that is composed of varying amounts of stroma and epithelium. Stroma is composed of varying amounts of collagen and smooth muscle [2]. The enlarged prostate can lead to bladder outlet obstruction which manifests clinically as LUTS. The size of the prostate is not a reliable predictor of the severity of LUTS $[3,4]$.

Pressure flow studies remain the gold standard to diagnose bladder outlet obstruction [5]. However, they are invasive, because catheterization is required to measure detrusor and urethral pressure, and they are uncomfortable for patients because of pain and voiding difficulty. Another important limitation of pressure flow study is the need for expensive equipments which are not readily available in many parts of the developing world. Thus, the need for a noninvasive, reliable and cost-effective alternative has lead to suggestion of surrogates like intravesical prostatic protrusion (IPP). Ultrasonographic measurement of IPP is able to detect bladder outlet obstruction in patients with benign prostate hyperplasia quickly and noninvasively [6]. Intravesical prostatic protrusion is the distance in millimeters between the tip of the prostate median lobe and bladder neck in the midsagittal plane, using a suprapubically positioned ultrasound scanner.

The intravesical prostatic protrusion distance can be divided into three grades: grade I: $0-4.9 \mathrm{~mm}$, grade II: 5-10 mm, and grade III: more than $10 \mathrm{~mm}$ [7]

Studies have shown that IPP is a reliable predictor of bladder outlet obstruction index (BOOI) as measured by pressure flow studies $[8,9]$.

The severity of lower urinary tract symptoms can be measured reliably with a number of validated questionnaires like International Prostate Symptoms Score (IPSS), Boyarsky score, Madsen score, Iversen score and Danish prostatic symptom score. The IPSS is recommended as the symptom scoring instrument to be used for the baseline assessment of symptom severity in men presenting with lower urinary tract symptom [10].

The present study will aim to determine the correlation between intravesical prostatic protrusion (IPP) and International Prostate Symptoms Score (IPSS).

\section{Methods}

The study was conducted at the Division of Urology, Department of Surgery, in our center, between September 2015 and August 2016. Approval was obtained from the health research ethics committee (HREC) prior to the commencement of the study. A written informed consent was obtained from all participants. All adult males greater than 50 years, presenting with LUTS and an enlarged prostate on DRE or ultrasound, were included in the study. Patients on medical therapy for BPH, BPH coexisting with urethral stricture, suspected prostate cancer and those with neurogenic bladder were excluded.

All enrolled patients were evaluated at the time of initial visit using the IPSS questionnaire. A digital rectal examination was done on each patient to assess the prostate size and characteristics. Uroflowmetry was done using ARK Meditech System Uroflowmetry Machine: Urol 010 Model. The abdominal ultrasound was done using a Mindray Digital Ultrasonic Diagnostic Imaging System: Model DP-20 with an abdominal probe frequency of $3.5 \mathrm{MHz}$ by the same radiologist in the radiology department. IPP was measured when the bladder contained about $100-200 \mathrm{ml}$ of urine. This was measured as the distance in millimeters between the tip of the prostate median lobe and bladder neck in the midsagittal plane and divided into three grades (grade I: 0 $-4.9 \mathrm{~mm}$; grade II: $5.0-10.0 \mathrm{~mm}$; and grade III: greater than $10.0 \mathrm{~mm}$ ). The prostate volume and post-void residual urine were also determined.

The data obtained were recorded in a proforma and entered into statistical software. Statistical Package for Social Sciences (SPSS) software version 20 was used for data analysis. The correlation between IPP and IPSS was determined using Spearman correlation coefficient. The correlation between IPP and the surrogates of $\mathrm{BOO}$ (prostate volume, Qmax and PVR) was also determined using Spearman correlation coefficient. The correlation between the surrogates of BOO and IPSS was determined using Pearson's correlation coefficient. Statistical significance $(P)$ value was set at 0.05 . Statistical significance $(P)$ value was set at 0.05 .

\section{Results}

A total of 167 patients met the inclusion criteria. The mean age was $63.7 \pm 8.9$ years, with a range of 45-90 years. The peak age group was $60-69$ years as 
Table 1 Age distribution of 167 men with BOO secondary to BPH

\begin{tabular}{lcl}
\hline Age (years) & Frequency & Percentage \\
\hline $40-49$ & 12 & 7.1 \\
$50-59$ & 36 & 21.6 \\
$60-69$ & 73 & 43.7 \\
$70-79$ & 40 & 24.0 \\
$80-89$ & 4 & 2.4 \\
$90-99$ & 2 & 1.2 \\
Total & 167 & 100 \\
\hline
\end{tabular}

Table 2 Distribution of the study population according to IPP grading

\begin{tabular}{lcl}
\hline IPP grading & Frequency & Percentage \\
\hline Grade I $(<5 \mathrm{~mm})$ & 62 & 37.1 \\
Grade II $(5-10 \mathrm{~mm})$ & 21 & 12.6 \\
Grade III $(>10 \mathrm{~mm})$ & 84 & 50.3 \\
Total & 167 & 100 \\
\hline
\end{tabular}

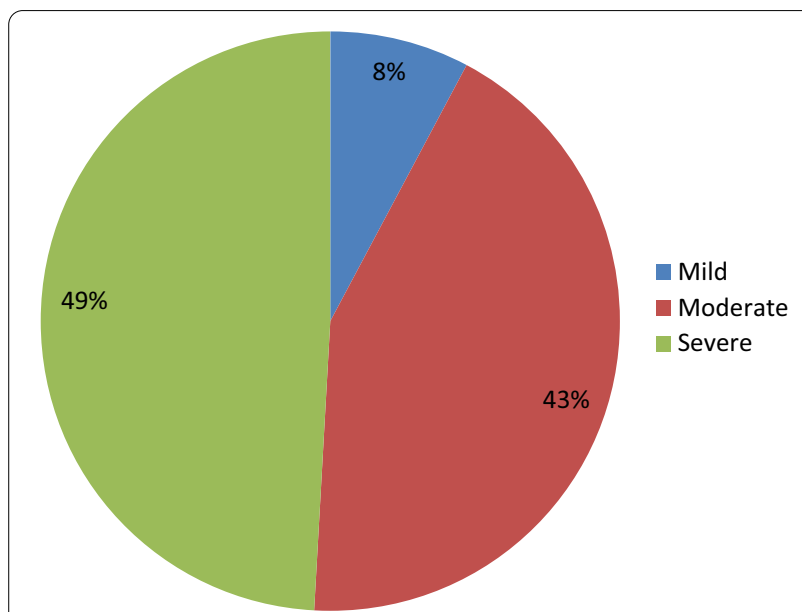

Fig. 1 A pie chart showing the frequency of severity of symptoms based on IPSS

shown in Table 1 . Majority (50.3\%) had grade III IPP as shown in Table 2.

The mean IPSS was $18.24 \pm 6.93$, with a range of $5-35$. Eighty-two patients (49.1\%) had severe symptoms; others are shown in Fig. 1.

The quality of life assessments showed that majority of the patients were unhappy with their symptoms (47.9\%) as shown in Fig. 2.

Eighty-two patients (49.1\%) had severe symptoms of which 23 patients (12.8\%), nine patients $(5.45 \%)$ and 50

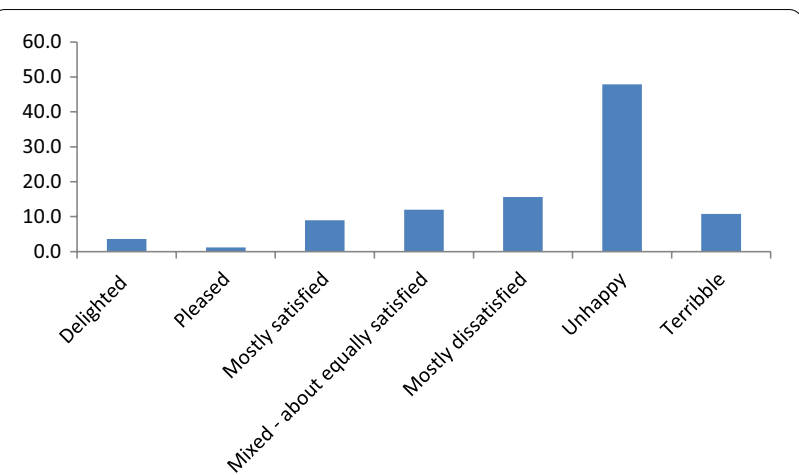

Fig. 2 A bar chart showing the quality of life assessment of the patients $(n=167)$

Table 3 Demographics and clinical characteristics of individual IPP category

\begin{tabular}{lllll}
\hline & Grade I & Grade II & Grade III & Total \\
\hline Mean age (years) & $61.65 \pm 7.5$ & $65 \pm 9.3$ & $65 \pm 9.6$ & $63.7 \pm 8.9$ \\
Mean IPP (mm) & $2.1 \pm 1.9$ & $7.8 \pm 1.0$ & $18.7 \pm 4$ & $10.2 \pm 8.0$ \\
Mean IPSS (total) & $16.23 \pm 6.9$ & $17.1 \pm 6.7$ & $20 \pm 6.6$ & $18.24 \pm 6.93$ \\
Mean IPSS (storage) & $7.61 \pm 3.6$ & $8.86 \pm 2.7$ & $9.5 \pm 3.2$ & $8.7 \pm 3.3$ \\
Mean IPSS (voiding) & $8.48 \pm 4.2$ & $8.29 \pm 4.8$ & $10.5 \pm 4.9$ & $9.4 \pm 4.7$ \\
Mean QoL & $4.06 \pm 1.2$ & $4.19 \pm 1.4$ & $4.48 \pm 1.2$ & $4.3 \pm 1.3$ \\
Mean PV (g) & $46.9 \pm 21.4$ & $64.1 \pm 41.3$ & $72.2 \pm 37.2$ & $64 \pm 34.7$ \\
Mean Qmax (ml/s) & $13.4 \pm 5.2$ & $13.8 \pm 6.0$ & $9.7 \pm 4.8$ & $11.6 \pm 5.4$ \\
Median PVR (ml) & 18 & 13.8 & 100 & 45 \\
\hline
\end{tabular}

patients (29.9\%) had grade I, grade II and grade III IPP, respectively. Seventy-two patients $(43.1 \%)$ had moderate symptoms of which 28 patients (16.8\%), 12 patients (7.2\%) and $32(19.2 \%)$ patients had grade I, grade II and grade III IPP, respectively. Thirteen patients (7.8\%) had mild symptoms of which 11 patients $(6.6 \%)$ and two patients (1.2\%) had grade I and grade III IPP, respectively.

The mean IPP was $10.2 \pm 8 \mathrm{~mm}$, with a range of $0-28.2 \mathrm{~mm}$. See Table 3 for the distribution of individual IPP category.

There was a positive correlation between the IPP versus IPSS storage, IPSS voiding, IPSS (total) and quality of life scores. The correlations were weak but statistically significant (Table 4).

The mean prostate volume was $64 \mathrm{~g} \pm 34.7$, with a range of $18.6-176.8 \mathrm{~g}$. Most (117 patients) had prostate volumes $\geq 40 \mathrm{~g}$, of which $21.6 \%, 10.2 \%$, and $38.3 \%$ had grades I, II and III IPP, respectively (Table 5).

The mean $\mathrm{Q} \max$ was $11.6 \mathrm{ml} / \mathrm{s} \pm 5.4$ with a range of $2-21 \mathrm{ml} / \mathrm{s}$. Seventy-seven (46.1\%) patients had flow $<10 \mathrm{ml} / \mathrm{s}$ of which $12 \%, 5.4 \%$, and $28.7 \%$ had grades 
Table 4 The correlation of grade of IPP with IPSS and quality of life

\begin{tabular}{lll}
\hline Variable & $\begin{array}{l}\text { Spearman's correlation } \\
\text { coefficient }\end{array}$ & $\boldsymbol{P}$ value \\
\hline IPPS (storage) & $0.245^{* *}$ & 0.001 \\
IPSS (voiding) & $0.187^{*}$ & 0.016 \\
IPSS (total) & $0.255^{* *}$ & 0.001 \\
QoL & $0.169^{*}$ & 0.029 \\
\hline
\end{tabular}

**Correlation is significant at the 0.01 level

*Correlation is significant at the 0.05 level

I, II, and III IPP, respectively. Most of the patients with grade III IPP had Q $\max <10 \mathrm{ml} / \mathrm{s}$ (Table 5).

The median PVR was $45 \mathrm{ml}$ with a range of $0-400 \mathrm{ml}$. only $14.4 \%$ had PVR $\geq 200 \mathrm{ml}$, most of them with grade III IPP.

Intravesical prostatic protrusion had positive correlation with prostate volume and post-void residual.
Intravesical prostatic protrusion also had a negative correlation with the $\mathrm{Q}$ max. The correlations were all statistically significant (Table 5 ).

There was a positive correlation between the IPSS (voiding, storage and total) and post-void residual urine; this was found to be statistically significant. There was negative correlation between the IPSS (voiding, storage and total) and Qmax. This was also found to be statistically significant (Table 6).

However, there was no correlation between the prostate volume and the IPSS (voiding, storage and total) (Table 6).

\section{Discussion}

A total of 167 patients were evaluated for BOO secondary to $\mathrm{BPH}$ during the study period. The mean age was 63.7 years \pm 8.9 years, with a range of $45-90$ years. The mean age is similar to the findings of Udeh et al. [11] in north central Nigeria who reported a mean age of $65.6 \pm 9.84$ years, and Badmus et al. [12] in south western

Table 5 Distribution of prostate volume, Q max and PVR among different grades of IPP and their correlation with IPP

\begin{tabular}{|c|c|c|c|c|c|c|}
\hline \multirow[t]{2}{*}{ Variable } & \multicolumn{4}{|c|}{ IPP, number (\%) } & \multicolumn{2}{|c|}{ Correlation with IPP } \\
\hline & Grade I & Grade II & Grade III & Total & $\overline{r_{s}^{*}}$ & $P$ value \\
\hline \multicolumn{7}{|c|}{ Prostate volume } \\
\hline $\begin{array}{l}<40 \mathrm{~g} \\
40-100 \mathrm{~g} \\
>100 \mathrm{~g}\end{array}$ & $\begin{array}{l}26(15.6 \%) \\
36(21.6 \%) \\
0\end{array}$ & $\begin{array}{l}4(2.4 \%) \\
13(7.8 \%) \\
4(3 \%)\end{array}$ & $\begin{array}{l}20(12 \%) \\
48(28.7 \%) \\
16(9 \%)\end{array}$ & $\begin{array}{l}50(29.9 \%) \\
97(58.1 \%) \\
20(12 \%)\end{array}$ & 0.328 & 0.000 \\
\hline \multicolumn{7}{|l|}{ Q max } \\
\hline $\begin{array}{l}<10 \mathrm{ml} / \mathrm{s} \\
10-15 \mathrm{ml} / \mathrm{s} \\
>15 \mathrm{ml} / \mathrm{s}\end{array}$ & $\begin{array}{l}20(12 \%) \\
14(8.4 \%) \\
28(16.7 \%)\end{array}$ & $\begin{array}{l}9(5.4 \%) \\
0 \\
12(7.2 \%)\end{array}$ & $\begin{array}{l}48(28.7 \%) \\
26(15.6 \%) \\
10(6.0 \%)\end{array}$ & $\begin{array}{l}77(46.1 \%) \\
40(24 \%) \\
50(29.9 \%)\end{array}$ & -0.291 & 0.000 \\
\hline \multicolumn{7}{|l|}{ PVR } \\
\hline $\begin{array}{l}<50 \mathrm{ml} \\
50-199 \mathrm{ml} \\
\geq 200 \mathrm{ml}\end{array}$ & $\begin{array}{l}40(24 \%) \\
14(8.4 \%) \\
4(2.4 \%)\end{array}$ & $\begin{array}{l}13(7.8 \%) \\
6(3.6 \%) \\
2(1.2 \%)\end{array}$ & $\begin{array}{l}26(15.6 \%) \\
40(24 \%) \\
18(10.8 \%)\end{array}$ & $\begin{array}{l}83(49.7 \%) \\
60(35.9 \%) \\
24(14.4 \%)\end{array}$ & 0.422 & 0.000 \\
\hline
\end{tabular}

Correlation is significant at the 0.01 level

$r_{s}^{*}$ :Spearman's correlation coefficient

Table 6 The correlation of prostate volume, Qmax and PVR with IPSS and QoL

\begin{tabular}{|c|c|c|c|c|}
\hline & & Prostate volume & $Q_{\max }$ & $\begin{array}{l}\text { Post-void } \\
\text { residual } \\
\text { urine }\end{array}$ \\
\hline IPSS (storage) & $\begin{array}{l}\text { Pearson correlation } \\
P \text { value }\end{array}$ & $\begin{array}{l}0.057 \\
0.464\end{array}$ & $\begin{array}{l}-0.181 \\
0.019\end{array}$ & $\begin{array}{l}0.225 \\
.004\end{array}$ \\
\hline IPSS (voiding) & $\begin{array}{l}\text { Pearson correlation } \\
P \text { value }\end{array}$ & $\begin{array}{l}0.104 \\
0.180\end{array}$ & $\begin{array}{l}-0.254 \\
0.001\end{array}$ & $\begin{array}{l}0.262 \\
0.001\end{array}$ \\
\hline IPSS (total) & $\begin{array}{l}\text { Pearson correlation } \\
P \text { value }\end{array}$ & $\begin{array}{l}0.099 \\
0.205\end{array}$ & $\begin{array}{l}-0.260 \\
0.001\end{array}$ & $\begin{array}{l}0.285 \\
0.000\end{array}$ \\
\hline QoL & $\begin{array}{l}\text { Pearson correlation } \\
P \text { value }\end{array}$ & $\begin{array}{l}0.019 \\
0.810\end{array}$ & $\begin{array}{l}-0.119 \\
0.127\end{array}$ & $\begin{array}{l}0.308 \\
0.000\end{array}$ \\
\hline
\end{tabular}

$P<0.05$ is significant 
Nigeria who reported a mean age of $64.4 \pm 8.88$ years. Similar findings have also been reported by other studies $[13,14]$. Most of the patients in this study presented in the seventh decade. The peak age of presentation is similar to the findings of Udeh and Movsav et al. [11, 15].

The mean IPSS was $18.24 \pm 6.93$, which was within moderate score on IPSS. Severe symptoms on IPSS were found in $49.1 \%$, while $43.1 \%$ had moderate symptoms and $7.8 \%$ had mild symptoms. There are studies (in patients with $\mathrm{BPH} \pm \mathrm{IPP}$ ) that have reported the mean IPSS both in the moderate $[14,16]$ and severe range $[17,18]$. The preponderance of severe symptoms can be partly explained by fact that the Urology clinic in our hospital is a referral center; patients are more likely to be referred to the Urologists if their symptoms are bothersome (moderate to severe score on IPSS). A population-based study is likely have more patients with mild symptoms compared to hospital-based studies. Ezeanyika et al. [19] in a population-based study in Nsukka, Nigeria, on males without apparent symptoms of ill health reported $74.65 \%$ as having mild symptoms on IPSS, while $23.58 \%$ and $1.77 \%$ had moderate and severe symptoms, respectively. Another possible explanation as to why most patients present with moderate to severe symptoms is that many men often attribute the changes in urinary pattern to inevitable consequence of aging, they eventually present to the Urologist when the symptoms become bothersome as noted by Oranusi et al. [20].

The QoL score showed that most patients were unhappy with their symptoms (46.1\%). There was also a strong positive correlation between the IPSS and QoL. This is similar to the findings of Adegun et al. [21]. They further suggested that the QoL should serve as the basis of treatment rather than the IPSS.

The mean IPP in this study was $10.3 \mathrm{~mm}$ which was within grade III IPP. This is similar to the findings of Agbo [22] and Sidgel et al. [23] who reported mean IPP of $12.9 \mathrm{~mm}$ and $14.6 \mathrm{~mm}$, respectively. About half of the patients $(50.3 \%)$ had grade III IPP. This is comparable with the findings of Reis et al. [13] and Eze et al. [24] in which grade III IPP constituted $59.5 \%$ and $59.4 \%$ of their study populations, respectively. However, there are other studies with preponderance of IPP grade I and grade II. $[25,26]$ Kuei et al. [26] in a study of Asian population reported $66.1 \%, 18.8 \%$ and $15.2 \%$ for grade I, grade II and grade III, respectively. The mean prostate volume in that study was $40 \mathrm{ml}$. The geographical location and smaller mean prostate volume may explain why there was preponderance of grade I IPP.

In this study, there was a significant positive correlation between the IPP and IPSS, IPSS sub scores and QoL. This finding is supported by several studies that have reported a significant positive correlation between the IPP and
IPSS [22, 24, 27, 28]. However, there are other studies that did not reveal any correlation between IPP and IPSS [23, 29]. This can be attributed to a number of factors. It has been noted that different bladder volumes affect the degree of protrusion of the prostate into the bladder, which eventually affect the grading of IPP [30]. Too little urine allows more protrusion of the prostate into the bladder, while a full bladder will reduce the protrusion of the prostate into the bladder. Yuen et al. [30] in a study to determine the effect bladder volume on prostatic protrusion concluded that IPP should be measured between 100 and $200 \mathrm{ml}$. Sidgel et al. [23] used a different bladder volume to measure the IPP (150-250 ml), while Hou et al.[29] did not mention the bladder volume at which IPP was measured. Measurement of IPP is also operator dependent, Hou et al. [29] was not explicit whether they used a single radiologist or otherwise.

There are several studies that shown IPP as a reliable predictor of BOOI as measured by pressure flow studies $[8,9]$. Chia et al.[8] considered IPP to be a useful parameter to predict $\mathrm{BOO}$ because of its good correlation with conventional pressure flow studies. Chia et al. [8] also found that $75 \%$ of men with significant BOO had IPP greater than $10 \mathrm{~mm}$, whereas only $8 \%$ of men with no significant BOO had IPP greater than $10 \mathrm{~mm}$. Keqin $\mathrm{Z}$ et al.[9] found that IPP was positively correlated with bladder outlet obstruction index. IPP greater than $10 \mathrm{~mm}$ appeared more often in the obstructed patients.

This study revealed a significant positive correlation between IPP and other parameters of BOO (PV, Qmax and PVR).

Lee et al.[28] in a prospective study of 114 men with $\mathrm{BOO}$ secondary to $\mathrm{BPH}$, found a positive correlation between IPP and prostate volume. Both IPP and PV had a significant positive correlation with BOOI; however, IPP had a better correlation with BOOI than prostate volume. Han et al.[31] also reported significant positive correlation between IPP with prostate volume $(r=0.534$, $P<0.01)$. Gyawali et al.[32] had a different outcome, in a prospective study of 60 men with LUTS; found that IPP had no correlation with PV. This study however had a smaller sample size.

The mean Qmax in this study was $11.6 \mathrm{ml} / \mathrm{s}$. Most men with grade III IPP had flow $<10 \mathrm{ml} / \mathrm{s}$. There was a significant negative correlation between the IPP and Qmax. Similarly Han et al. found out that the degree of IPP is negatively correlated with the Qmax $(-0.364$, $P<0.01$ )[31]. Liber et al.[33] in a sample of 322 men residing in Olmsted county, reported significant correlation between IPP and higher obstructive symptoms and Qmax $(r=-0.18, P<0.01)$. However, Sidgel et al.[23] in a prospective study of 50 patients with $\mathrm{BPH}$ reported IPP had a positive correlation with Qmax, but it was not 
statistically significant. This outcome of Sidgel et al. could have been affected by the small sample size.

In this study, IPP had a significant positive correlation with PVR urine. This has also been reported from other studies $[28,29]$.

In this study, both the Qmax and PVR urine had a significant correlation with the IPSS. Barry MJ and Girman CJ [34], Bosch et al.[35] and Din et al.[36] have reported weak but significant correlations between Qmax and symptom scores, while Singla et al.[37] and Kolman C et al.[38] both reported significant positive correlation between PVR urine and IPSS.

In this study, there was no correlation between prostate volume and IPSS. There are studies that have reported similar findings [39, 40]. Symptoms severity is determined by other factors and not necessarily the size of the prostate alone.

Apart from predicting symptoms severity, IPP can also be useful predictor for successful trial without catheter (TWOC). A TWOC is more likely to fail in patients with IPP larger than $10 \mathrm{~mm}$ [41]. Patients with grade III IPP can be identified earlier as such patients are more likely to require surgical intervention [42].

\section{Conclusion}

Intravesical prostatic protrusion is a reliable predictor of severity of LUTS as measured by IPSS. Patients with grade III IPP are likely to present with severe symptoms. IPP also shows good correlation with other surrogates of BOO (prostate volume, Qmax and post-void residual urine).

\section{Abbreviations}

BPE: Benign prostatic enlargement; BPH: Benign prostate hyperplasia; $\mathrm{BOO}$ : Bladder outlet obstruction; DRE: Digital rectal examination; IPSS: International Prostate Symptoms Score; QoL: Quality of life; IPP: Intravesical prostatic protrusion; PV: Prostate volume; PVR: Post-void residual; LUTS: Lower urinary tract symptoms; Qmax: Peak flow rate; SPSS: Statistical package for the social sciences; PFR: Peak flow rate.

\section{Acknowledgements}

Not applicable.

\section{Authors' contributions}

B.K.H. contributed to project development, manuscript writing, data collection, data analysis and editing. M.A (Ahmed), A. B and H.Y.M helped with project development and editing. M.A.T contributed to data collection, data analysis, and editing. M.A (Awaisu), A.T. L, N.O, K.I.A, L. L and A. S helped with data collection and editing. All authors have read and approved the manuscript.

\section{Funding}

None.

\section{Availability of data and materials}

Raw data are available at the request of the author.
Ethical approval and consent to participate

This study was approved by the health research ethics committee (HREC) of Ahmadu Bello University Teaching Hospital Zaria (Reference number: ABUTHZ/HREC/N09/2015). A written informed consent was obtained from all participants.

\section{Consent for publication}

Not applicable.

\section{Competing interests}

None.

\section{Author details \\ ${ }^{1}$ Kaduna State University, Kaduna, Nigeria. ${ }^{2}$ Ahmadu Bello University Teaching Hospital, Zaria, Nigeria. ${ }^{3}$ Ahmadu Bello University Zaria, Zaria, Nigeria.}

Received: 23 April 2020 Accepted: 14 December 2020

Published online: 07 January 2021

\section{References}

1. Chute CG, Panser LA, Girman CJ, Oesterling JE, Guess HA, Jacobsen SJ et al (1993) The prevalence of prostatism: a population-based survey of urinary symptoms. J Urol 150:85-89

2. Presti JC Jr, Christopher J, Kane M, Kausto Shinohara M, Peter R, Carroll M (2008). Neoplasm of the prostate gland. In: Smith's general urology, 17th edn. McGraw-Hill, p 349.

3. Agrawal CS, Chalise PR, Bhandari BB (2008) Correlation of prostate volume with international prostate symptom score and quality of life in men with benign prostatic hyperplasia. Nepal Med Coll J 10:104-107

4. Ofoha CG, Shu SI, Akpayak IC, Dakum NK, Ramyil VM (2013) Relationship between Prostate volume and IPSS in African men with Prostatic disease. JOS J Med 9:16-19

5. Nitti VW (2005) Pressure flow urodynamic studies: the gold standard for diagnosing bladder outlet obstruction. Rev Urol 7:14-21

6. Hossain AKMS, Alan AKMK, Habib AKMK, Rashid MM, Rahman H et al (2012) Comparison between prostate volume and intravesical prostatic protrusion in detecting bladder outlet obstruction due to benign prostatic hyperplasia. Bangladesh Med Res Counc Bull 38(1):14-17

7. Bachmann A, Descazeaud A, Emberton M, Gravas S, Michel MC, Nordling J (2012). Guidelines on male lower urinary tract symptoms (LUTS ), including Benign Prostatic Obstruction (BPO). Eur Assoc Urol 123-144.

8. Chia SJ, Heng CT, Chan SP, Foo KT (2003) Correlation of intravesical prostatic protrusion with bladder outlet obstruction. BJU Int 91:371-374

9. Keqin Z, Zhishun X, Jing Z, Haixin W, Dongqing Z, Benkang S (2007) Clinical significance of intravesical prostatic protrusion in patients with benign prostatic enlargement. Urology 70:1096-10999

10. McNicholas TA, Kirby RS, Lepor H (2012) Evaluation and Nonsurgical management of Benign Prostate Hyperplasia. In: Campbell-walsh urology, 10th edn. Elseivier, pp 2615-2616

11. Udeh El, Ozoemena OF, Ogwuche E (2013) The relationship between prostate volume and international prostate symptom score in Africans with benign prostatic hyperplasia. Niger J Med 21:120-125

12. Badmus TA, Asaleye CM, Badmus SA, Takure AO, Ibrahim MH, Arowolo OA (2012) Benign prostate hyperplasia : average volume in southwestern Nigerians and correlation with anthropometrics. Niger Postgrad Med J 19:15-18

13. Reis LO, Barreiro GC, Baracat J, Prudente A, D'Ancona CA (2008) Intravesical protrusion of the prostate as a predictive method of bladder outlet obstruction. Int Braz J Urol 34:627-633

14. Mohammed AZ, Alhassan SU, Edino ST, Ochicha O (2003) Histopathological review of prostatic diseases in Kano. Nigeria Niger Postgrad Med J 10:1-5

15. Movsas S (1966) Prostatic obstruction in the African and Asiatic. Br J Surg 53:538-543

16. Hou CP, Lin YH, Chen CL, Tsai YL, Chang PL, Tsui KH (2016) Impact of the static prostatic urethral angle on men with lower urinary tract symptoms. Urol Sci 27:47-50 
17. Ogwuche El, Dakum NK, Amu CO, Dung ED, Udeh E, Ramyil VM (2013) Problems with administration of International Prostate Symptoms Score in a developing country. Ann Afr Med 12:171-173

18. Puthenveetil RT, Baishya D, Barua S, Sarma D (2015) Implication of ultrasound bladder parameters on treatment response in patients with benign prostatic hyperplasia under medical management. Asian J Urol 2:233-237

19. Ezeanyika LUS, Ejike ECC, Obidoa O, Elom SO (2006) Prostate disorders in an apparently normal Nigerian population 1: Prevalence. Biokemistri 18:127-132

20. Oranusi CK, Nwofor AE, Mbonu O (2017) Correlation between international prostate symptom score and uroflowmetry in patients with benign prostatic hyperplasia. Niger J ClinPract 20:454-458

21. Adegun PT, Adebayo PB, Areo PO (2016) Severity of lower urinary tract symptoms among middle aged and elderly Nigerian men: impact on quality of life. Adv Urol 2016

22. Agbo CA, Ramyil VM, Dakum NK, Shuaibu SI, Onowa VE, Nabasu LE, Gallam ZZ, Ukaonu BC (2018) The value of intravesical prostatic protrusion from benign prostate enlargement in Nigeria. Afr J Urol 24:342-346

23. Sigdel G, Belokar WK (2015) Clinical significance of intravesical prostatic protrusion in patients with Benign Prostatic Hyperplasia. J Univ Coll Med Sci 3:6-10

24. Eze BU, Mbaeri TU, Oranusi KC, Abiahu JA, Nwofor AM, Orakwe JC, Mbonu OO (2019) Correlation of Intravesical prostatic protrusion and international prostate symptoms score among Nigerian men with benign prostatic hyperplasia. Niger J ClinPract 22:454-459

25. Lee LS, Sim HG, Lim KB, Wang D, Foo KT (2010) Intravesical prostatic protrusion predicts clinical progression of benign prostatic enlargement in patients receiving medical treatment. Int J Urol 17:69-74

26. Kuei CH, Liao CH, Chiang BJ (2016) Significant intravesical prostatic protrusion and prostatic calcification predict unfavorable outcomes of medical treatment for male lower urinary tract symptoms. Urol Sci 27:13-16

27. Park YJ, Bae KH, Jin BS, Jung HJ, Park JS (2012) Is increased prostatic urethral angle related to lower urinary tract symptoms in males with benign prostatic hyperplasia/lower urinary tract symptoms? Korean J Urol 53:410-413

28. Lee A, Lee HJ, Lim KB, Huang HH, Ho H, Foo KT (2015) Can intravesical prostatic protrusion predict bladder outlet obstruction even in men with good flow? Asian J Urol 3:39-43

29. Hou CP, Lin YH, Chen CL, Tsai YL, Chang PL, Tsui KH (2014) Impact of the static prostatic urethral angle on men with lower urinary tract symptoms. Urol Sci 27:47-50

30. Yuen JSP, Ngiap JTK, Foo CWSCAKT (2002) Effects of bladder volume on transabdominal ultrasound measurements of intravesicalprostatic protrusion and volume. Int J Urol 9:225-229

31. Han WK, Shan GZ, Jin J (2010) Correlation of intravesical prostatic protrusion with clinical evaluation parameters in $\mathrm{BPH}$ patients. Zhonghua Nan KeXue 16:254-257
32. Gyawali PR, Shrestha GK, Joshi BR, Chalise PR, Sharma UK (2010) Intravesical prostatic protrusion is better than prostate volume in predicting symptom severity in Benign Prostatic Hyperplasia: A Prospective Clinical Study. Post Graduate Med J NAMS 10:24-28

33. Lieber MM, Jacobson DJ, Mcgree ME (2010) Intravesical prostatic protrusion in Olmsted County, Minnesota. J Urol 182:2819-2824

34. Barry MJ, Girman CJ et al (1995) Using repeated measures of symptom score, uroflowmetry and prostate specific antigen in the clinical management of prostate disease. Benign Prostatic Hyperplasia Treatment Outcomes Study Group. J Urol 153:99-103

35. Bosch JLHR, Hop WCJ, Kirkels WJ, Schrosber FH (1995) The International Prostate Symptom Score in a community based sample of men between 55 and 74 years of age; prevalence and correlation of symptoms with age, prostate volume, flow rate and residual urine volume. $\mathrm{Br} J$ Urol 75:622-630

36. Din KEE, Kiemeney LAAM, Wildt MJAM, Debruyne FMJ, Rosette JJMC (1996) Correlation between uroflowmetry, prostate volume, postvoid residual, and lower urinary tract symptoms measured by the International Prostate Symptom Score. Urology 48:393-397

37. Singla S, Garg R, Singla A, Sharma S, Singh J, Sethi P (2014) Experience with uroflowmetry in evaluation of lower urinary tract symptoms in patients with benign prostatic hyperplasia. J ClinDiagn Res 8:NC01-NC03

38. Kolman C, Girman CJ, Jacobsen SJ, Lieber MM (1999) Distribution of postvoid residual urine volume in randomly selected men. J Urol 161:122-127

39. Barry MJ, Fowler FJ, O'Leary MP, Bruskewitz RC, Holtgrewe HL, Mebust WK et al (1992) The American Urological Association symptom index for BPH. J Urol 5:1549-1557

40. Frank J, Thomas K, Oliver S, Andrews S, Choong S, Taylor R, Emberton M (2001) Couch or crouch? Examining the prostate, a randomized study comparing the knee-elbow and the leftlateral position. BJU Int 87:331-333

41. Mariappan P, Brown DJG, McNeill AS (2007) Intravesical prostatic protrusion is better than prostate volume in predicting the outcome of trial without catheter in white men presenting with acute urinary retention: a prospective clinical study. J Urol 178:573-577

42. Tan YH, Foo KT (2003) Intravesical prostatic protrusion predicts the outcome of a trial without catheter following acute urine retention. J Urol 170:2339-2341

\section{Publisher's note}

Springer Nature remains neutral with regard to jurisdictional claims in published maps and institutional affiliations.

\section{Submit your manuscript to a SpringerOpen ${ }^{\circ}$ journal and benefit from:}

- Convenient online submission

- Rigorous peer review

- Open access: articles freely available online

- High visibility within the field

Retaining the copyright to your article

Submit your next manuscript at springeropen.com 